
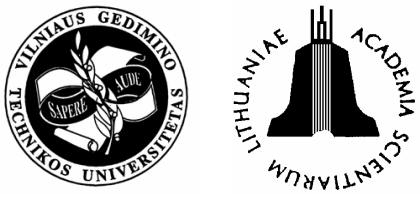

\title{
INTEGRATED AGENT-BASED CONSTRUCTION EQUIPMENT MANAGEMENT: CONCEPTUAL DESIGN
}

\author{
Omer Tatari $^{1}$ and Mirosław Skibniewski ${ }^{2}$ \\ ${ }^{1}$ PhD Candidate, School of Civil Engineering, Purdue University, West Lafayette, IN 47907-2051, USA \\ ${ }^{2}$ A. James Clark Endowed Chair Professor, Dept of Civil \& Environmental Engineering, University of \\ Maryland, College Park, MD 20742-3021,USA mirek@umd.edu; Member of the Graduate School \\ Faculty, Purdue University, West Lafayette, IN 47907, USA \\ Received 22 March 2006; accepted 09 May 2006
}

\begin{abstract}
Effective management of equipment is crucial for the success of construction firms. Inadequate manual processes of equipment management and the subjective decisions of equipment managers usually result in major losses in construction firms, hence, the economy. The main purpose of this paper is to introduce an agent-based equipment management system aiming to increase integration and automation, and to minimise decision errors. Recent research on agent technology allows the proposition of an automated and integrated application for equipment management. The proposed application makes use of the current databases of the firm and adds wireless technology to construction equipment for automated data integration.
\end{abstract}

Keywords: equipment management, agent technology, construction industry.

\section{Introduction}

Construction equipment is one of the most important physical assets in a construction firm. It plays an important role in construction operations and constitutes a major portion of construction projects. According to a research that surveyed ENR's (Engineering News Record) top 400 contractors, nearly $50 \%$ of the construction firms own the equipment they use (Tavakoli et al, 1989). Hence, proper management of equipment is crucial for the firm success, especially for the construction industry where profit margin is very low. It is important to note that effective management of equipment would engender large savings for construction firms.

Numerous software solutions have been developed to aid the equipment manager with the decision process. However, most of these solutions serve only as a database management system. Moreover, most of the expert systems that assist earthmoving operations are not integrated with the information and cost management and control systems of the firm. Therefore, these systems do not provide a sufficient solution to the inherent integration of information problem.

This paper proposes an agent-based integrated equipment management system (ABEMS) that seamlessly integrates the entire construction equipment management with the enterprise resource planning (ERP) system of the firm. Moreover, with the aid of agent and wireless technologies, an automated solution that minimises human interaction is suggested.

\section{Current equipment management practices}

Construction equipment management is concerned with the purchase, retirement, replacement, operations, logistics, and maintenance of equipment. The objective of the firm is to minimise operation, maintenance, and repair costs, while achieve high utilisation of the construction equipment. These responsibilities could be categorized into two groups: operational and strategic responsibilities (Table 1). Operational responsibilities consist of day-today management of construction equipment. Generally, these decisions are given by project managers, who are assigned to specific equipment for specific time by the equipment managers of the firm.

Table 1. Operational and strategic dimensions of equipment management

\begin{tabular}{l|l}
\hline Operational & Strategic \\
\hline Maintenance & Equipment selection \\
Repair & Finance \\
Logistics & Replacement \\
Fueling & Disposal \\
Life-cycle costing & \\
\hline
\end{tabular}

In most of the construction firms, equipment managers are the sole undertakers of the overall responsibility of equipment management. Based on their experience, equipment managers decide on the day-to-day management of equipment operations, and also on strategic operations such as new equipment procurement. Thus, 
responsibilities of the equipment managers, ensuring that the equipment is properly used, maintained, utilised and managed, are rather challenging. Effective operation of construction equipment should be maintained to avoid under utilisation of such large capital investment. Also, preventive maintenance and repair should be carefully planned, and high productivity rates should be realised during operations. As the equipment fleet gets larger, maintaining such goals become a big challenge.

Most construction firms have centralised equipment management function, but actual operations are geographically dispersed. Even though the equipment manager of the firm is the main accountable, responsibilities are shared with project managers that utilize the equipment during project.

\section{Equipment management processes}

Management of construction equipment can be analysed in three processes (Fig 1). These processes constitute the decisions with respect to the life cycle of the equipment. Each of these processes can be further divided into sub-processes.

\subsection{Acquire}

With the undertaking of new projects and the retirement of old machinery and equipment, it becomes necessary to acquire new construction equipment. In this stage, sufficient knowledge base of current brands and products is necessary. It is also important to determine what sort of equipment and capacity is needed. In fact, selection of equipment for the project is one of the key decisions in planning and executing a construction project, which affects how the work will be done, the time required to complete the work, and the cost that will be accrued (Schaufelberger, 1999).
Generally, an equipment manager is responsible of acquiring the equipment, whereas it is the responsibility of the construction planning group to select equipment. Nevertheless, both the inventory of equipment in hand and the standard equipment policy play an important role in equipment selection. Therefore, final decision on the equipment required for the projects is generally given by equipment managers, project managers, and construction planning group together. Often, the decision making process can create tensions in the firm.

Once the selection of equipment is made, a choice has to be made whether to buy, rent, or lease it. These decisions are given based on the economic standing and strategy of the firm, and the nature and frequency of equipment use.

\subsection{Utilise}

This stage includes operations and maintenance of construction equipment. In this stage, the equipment in use should be maintained properly, by scheduling preventive maintenance periods. Scheduled maintenance reduces the incidents of failure, and thus minimizes costly breakdowns and stoppages on the project site. In manufacturing industry, preventive maintenance has increased the production level around 10-20\%, by reducing the break-down time of the equipment (Anderson, 1994). For high utilization rates, the equipment should be kept in a good condition. Also, proper selection and training of operators and maintenance personnel is part of the responsibility of the equipment manager. In addition, safety of both the operators and the equipment should be considered and properly managed. Furthermore, proper registration and inventory records are part of the inventory process. Besides the equipment life cycle, equipment managers are also responsible or operating the equipment maintenance and storage facilities.

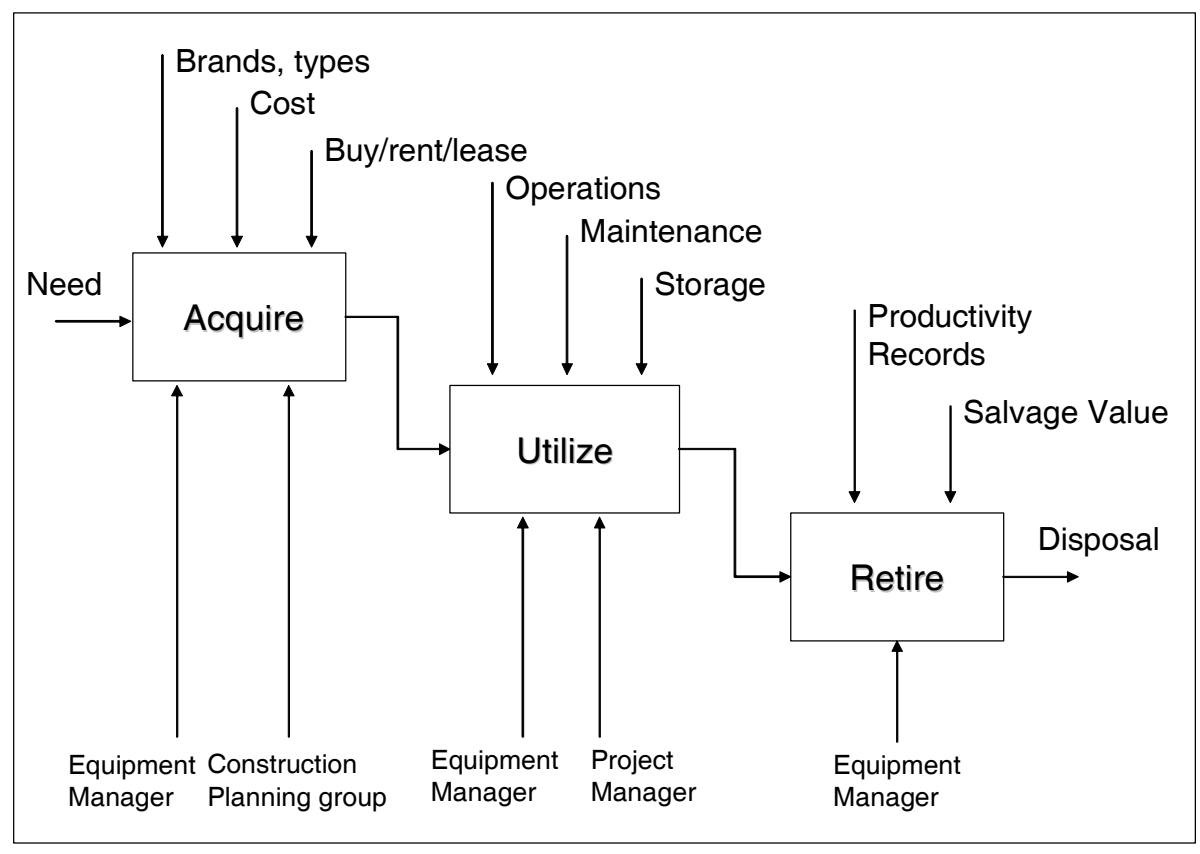

Fig 1. Equipment management processes 


\subsection{Retire}

The equipment that no longer attains certain productivity levels should be disposed. In order to decide whether to undertake a major maintenance of the equipment, or to salvage it, productivity and diagnosis records should be analysed rigorously. Even the salvage of the equipment should bring income to the construction firm. Often times, miscalculations of salvage value may bring losses to the firm.

\section{Current information technology (IT) solutions for equipment management}

Most of the construction firms have customised software for equipment management. In addition, standard software like MS Excel, MS Access, FoxPro, and Oracle are used to keep track of equipment data. Also, there are some off-the-shelf software solutions specifically designed for construction equipment management. Most of these solutions include modules to keep track of inventory, operations, and maintenance data, and generate reports in order to aid management decisions. On the other hand, there are some solutions that utilise wireless technology. These solutions include wireless data terminals for collecting data from equipment which is then integrated to the back office systems on real-time basis. This helps to improve the utilisation of equipment and to reduce operating costs.

Expert systems have been developed to assist the personnel responsible for equipment selection. VB-Expert was developed to aid equipment selection for earthmoving operations (Amirkhanain and Baker, 1992). ESACP was developed to assist planning and controlling of concrete placing operations (Alkass et al, 1993). There are many other expert systems that have been developed either for academic purposes or for commercial use. Yet, no reference with respect to an integrated equipment management system that includes all functionalities concerning the construction equipment could be cited.

On the other hand, major ERP vendors such as SAP, PeopleSoft, and Oracle, have developed special modules to manage construction equipment (Table 2). The most important advantage of implementing such modules is having seamless integration with the information and cost systems of the firm. To better understand the modules offered by ERP vendors, SAP's solution will be analysed in more detail. SAP is selected for further analysis since it is found the most sophisticated and construction-oriented solution in the market by the researcher.

Table 2. ERP modules for equipment management

\begin{tabular}{l|l}
\hline ERP Vendor & Module Name \\
\hline SAP & Fleet Equipment \& Tools Management \\
\hline PeopleSoft & Enterprise Asset Management \\
\hline Oracle & Enterprise Asset Management \\
\hline
\end{tabular}

\subsection{Analysis of SAP's fleet equipment management module}

SAP has developed an equipment management module based on the best-practices of several European construction firms (Table 3). It is important to note that, if implemented fully, SAP's current solution will have very powerful data tracking capabilities, and will cover the whole spectrum of equipment data. With the use of such a system, it would be easy to properly maintain and utilise construction equipment.

Table 3. SAP equipment management functions (SAP 2003)

\begin{tabular}{l|l}
\hline Function & Description \\
\hline Master Data & $\begin{array}{l}\text { Monitors master data for construction } \\
\text { equipment }\end{array}$ \\
\hline $\begin{array}{l}\text { Requirements Speci- } \\
\text { fication }\end{array}$ & $\begin{array}{l}\text { Specifies the characteristics of the } \\
\text { requirement as well as the dates for } \\
\text { the construction equipment }\end{array}$ \\
\hline $\begin{array}{l}\text { Plan- } \\
\text { ning/Scheduling/Disp } \\
\text { atching }\end{array}$ & $\begin{array}{l}\text { Plans, schedules and dispatches for } \\
\text { fleet and operator }\end{array}$ \\
\hline Journey Management & $\begin{array}{l}\text { Manages shipping and status of } \\
\text { equipment, fleet, and tools }\end{array}$ \\
\hline $\begin{array}{l}\text { Counter Measure- } \\
\text { ments }\end{array}$ & $\begin{array}{l}\text { Tracks counter measurements espe- } \\
\text { cially necessary for fleet objects } \\
\text { (odometer, hourmeter, and fuel and } \\
\text { oil consumption) }\end{array}$ \\
\hline $\begin{array}{l}\text { Maintenance \& } \\
\text { Overhaul }\end{array}$ & $\begin{array}{l}\text { Manages complete maintenance func- } \\
\text { tionality for vehicles }\end{array}$ \\
\hline $\begin{array}{l}\text { Warranty Manage- } \\
\text { ment }\end{array}$ & $\begin{array}{l}\text { Uses warranty information, for special } \\
\text { pricing procedures in case of damages }\end{array}$ \\
\hline ATA Codes & $\begin{array}{l}\text { Utilises American trucking associa- } \\
\text { tions (ATA) vehicle maintenance } \\
\text { reporting standard (VMRS) codes for } \\
\text { identification of components which } \\
\text { have been main- } \\
\text { tained/repaired/replaced, and reports } \\
\text { to government agencies using these } \\
\text { codes }\end{array}$ \\
\hline Billing \& Settlement & $\begin{array}{l}\text { Generates operation statistics and } \\
\text { reports }\end{array}$ \\
$\begin{array}{l}\text { Supports the financial processes for } \\
\text { the internal and external rental process }\end{array}$ \\
\hline
\end{tabular}

Another important advantage is the seamless integration of cost information between the equipment management and the accounting modules. Thus, cost figures of projects will automatically include equipment-based costs. Yet, the system is very similar to an advanced database management system and does not have expert functionalities. Its functionalities do not provide an enhanced intelligent tool that can automatically assess and analyse the status of equipment. Again, most of the decisions are left to the discretion of the equipment manager.

\section{Current problems in construction equipment man- agement}

As has been demonstrated above, equipment management is still dependant on the experience and assess- 
ment of human beings. Developed software solutions serve as a database that keeps record of equipment, and equipment managers rely on their experience in decision making. Although there are developed expert systems to assist the process, the researcher has found no evidence of a completely integrated system. Substantial investments such as equipment, which is a major undertaking by construction firms, should not be based on subjective and potentially inadequate judgments of human beings. Instead, a fully integrated agent-based equipment management system, which is integrated to the ERP system of construction firms is proposed.

The agent-based equipment management system (ABEMS) seeks to minimise human interference and judgment in the equipment management decision making process. A brief overview is given regarding agent-based systems, and followed by a detailed description of ABEMS.

\section{Agent-based systems}

Selker defines agents as "computer programs that simulate a human relationship by doing something that another person could do for you." An agent can be defined in terms of three behavioral attributes, any two of which need to exist to be considered a software agent (Nwana, 1996). Nwana (1996) defines them as:

- "Autonomy. This refers to the principle that agents can operate on their own without the need for human guidance, even though this would sometimes be invaluable. Hence agents have individual internal states and goals, and an agent acts in such a manner as to meet its goals on behalf of its user. An important element of their autonomy is their proactiveness, ie their ability to "take the initiative" rather than acting simply in response to their environment.

- Co-operation. Co-operation with other agents is paramount; it is the raison d'etre for having multiple agents in the first place in contrast to having just one. In order to co-operate, agents need to possess a social ability, ie the ability to interact with other agents and possibly humans via some communication language. Having said this, it is possible for agents to co-ordinate their actions without cooperation.

- Learning. For agent systems to be truly "smart", they would have to learn as they react and interact with their external environment. In our view, agents are or should be disembodied bits of "intelligence". Though we will not attempt to define what intelligence is, we maintain that an important attribute of any intelligent being is its ability to learn. The learning may also take the form of increased performance over time."

Typically, multi-agent systems (MAS) could be defined as a distributed system where several distinct agents come together to form a coherent whole (d'Inverno and Luck, 2001). These agents can also be heterogeneous.
Russell and Norvig (1995) summarise the strength of MAS in three aspects:

1) "Agents are intrinsically distributed. Their properties such as parallelism, robustness, and scalability make them well suited for domains which require resolution of interest and goal conflicts, integration of multiple knowledge sources and resources, timebounded processing of very large data sets, or online interpretation of data arising from different geographical locations.

2) Agent are in accordance with the insight gained in discipline such as AI, psychology, and sociology that intelligence is tightly and inevitably coupled with interaction.

3) The modularity of agents makes it natural to encapsulate humans as peer agents to computer processes using common language and protocols to integrate people and machines. In nature, this integration requires people to reduce the bandwidth of their communication to a level that computerised agents can handle."

MAS offer a powerful approach for developing heterogeneous complex environments. Particularly, it can play an important role for fragmented environments such as the construction industry (Ren and Anumba, 2004). It is widely acknowledged that other approaches are difficult to solve the inherent fragmentation problems, and MAS could provide a new approach to solve fragmentation problems (Ren and Anumba, 2004). With the use of MAS, large-scale problems could be resolved in an improved collaborative and concurrent setting (Ren and Anumba, 2004).

\section{ABEMS}

The system is modelled in a way that minimises human interference with respect to equipment management. This is accomplished through two important factors: realtime integration and autonomous agents. The ABEMS framework consists of a number of software tools and agents that support all the activities pertaining equipment management (Fig 2). These agents interact with each other in a heterogeneous and distributed environment to control the management of construction equipment.

\subsection{Procurement control}

In a typical construction firm, the project manager is the champion and responsible of a construction project. However, the project plans are generally ready before the project manager is assigned to the project. The primary responsibility of the project manager is to finish the project on-time and within the assigned budget. The construction planning group will decide on the number of equipment needed and their properties. Most often, this process takes a long time and is highly complicated. Moreover, human judgment plays an important role in these decisions. The number of equipment to be used and the varying equipment schedules further complicate the process. ABEMS procurement control module will have these functionalities: 
- Real-time information regarding the idle equipment,

- Real-time information regarding the equipment suppliers' availability of products,

- Real-time information regarding the rental and lease options,

- Equipment requirement planning for the project.

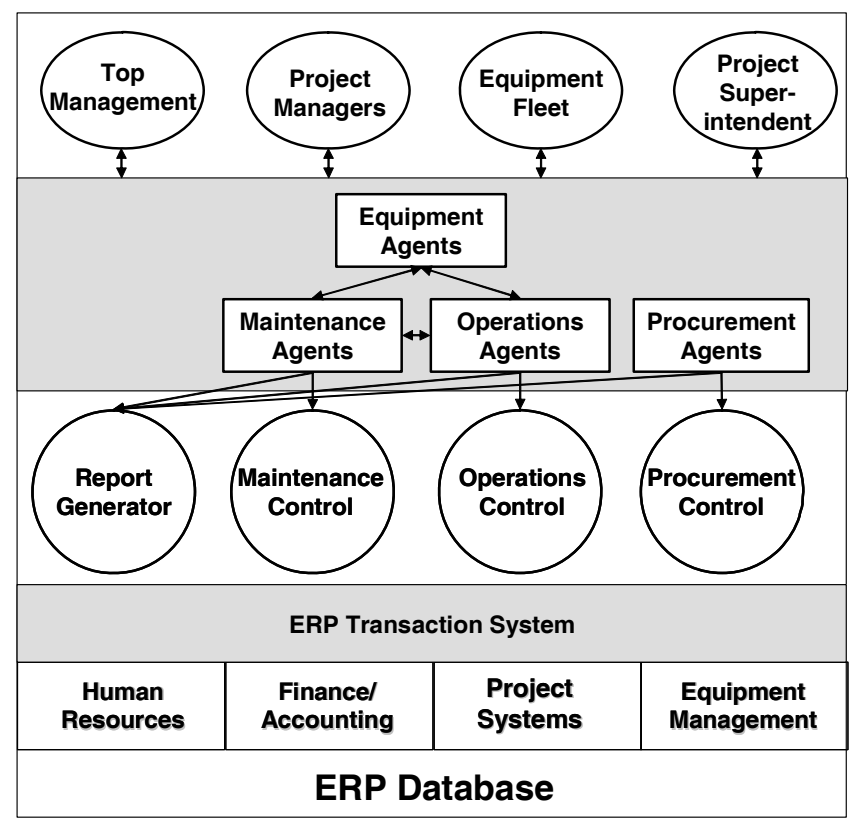

Fig 2. ABEMS framework

Procurement agents are intended to support equipment allocation and procurement activities. They will be fetching data automatically from the ERP database of the firm. Also, they will be getting quotes from different suppliers regarding their products. These agents will be responsible for generating an equipment strategy which incorporates the available equipment options for the appointed schedules.

Equipment procurement expert software will be encapsulated to do the necessary planning for the equipment. This system will consist of a GUI-enabled (graphical user interface enabled) interface, a requirement planning application layer, and agents that are constantly fetching data from the suppliers and the database.

\subsection{Operations control}

This module is responsible for the operations control of the equipment. Using wireless technology, construction equipment will send real-time information regarding its operations. Automatic and accurate data about equipment usage and utilisations will be processed and analysed by the operations agents. In each project, operations agent will collect necessary information and send it to the operations control software. If low utilisation rates or problems are anticipated, operations agent in the specific project will send warning messages to the project manager.

For this module to function effectively, properly designed operations control software is needed. This software should include a knowledge base regarding the standard utilisation and productivity rates, and should send warnings when these rates are not met, or if it senses an abnormality with the information it receives.

Also, with real-time data transfer, accrued costs regarding equipment operations and fuel consumption will be added to project costs automatically. That way, project managers will be able to see a more realistic and complete picture regarding the project. Moreover, top management will be able to have real-time data regarding the financial status of the project.

\subsection{Maintenance control}

Maintenance control module is a simple but powerful tool, which automatically informs the project managers when equipment's preventive maintenance time has come.

With the aid of maintenance agents, maintenance control software analyses the data regarding the operations of the equipment, and compares it with the original specifications. The maintenance agent receives data from the equipment agent that gathers all necessary data regarding the equipment. Also, when an unexpected breakdown occurs, maintenance agents send the appropriate message to the maintenance operators and automatically assign a time for scheduling. If there is a need to replace equipment, then procurement agents will be triggered to get the best estimate for new equipment or check the availability for idle equipment. Maintenance control software keeps the schedules of the maintenance operators and can assign the time automatically. Thus, without human interference, project superintendents and managers will be able to see on their screens when these equipments will be repaired.

\subsection{Report generator}

Report generator will get all the information from the agents on a periodic basis. The necessary data will automatically fill the specified cells in the report templates, and will subsequently be sent to top management and project managers as a professional report. That way, the status of construction equipment and their utilisation will be checked on a periodic basis.

\section{Conclusions}

Equipment management remains a critical competency for the success of construction firms. Even though there are many software solutions that aid in this process, equipment managers still use their subjective and potentially inadequate judgments in most of the equipment management decisions. Millions of dollars are wasted because of these misjudgments. In the highly competitive environment of the construction industry, where the profit margins rarely exceed $5 \%$, more knowledge driven solutions need to be utilised. Construction industry has yet to utilise the agent-based technologies and integrated systems.

This paper provided an overview of an equipment management system that can be used for better integration and automation. Moreover, taking into account the 
information overload and expectations from human operators, an agent-based architecture aiming to minimise human interference has been introduced. With the proposed solution, real-time data will be automatically transferred from equipment by the aid of wireless technology, and the autonomous agents will constantly evaluate these data to assist the project and equipment managers.Use of agent technology in the construction industry is expected to help solve the 'islands of automation' problem that causes lower productivity and quality.

\section{References}

Alkass, S.; Aronian, A. and Moselhi, O. (1993) Computer aided equipment selection for transporting and placing concrete. ASCE Journal of Construction Engineering and Management, 119(3), p. 445-465.

Amirkhanain, S. N. and Baker, N. J. (1992) Expert system for equipment selection for earthmoving operations. ASCE Journal of Construction Engineering and Management, 118(2), p. 318-331.

Anderson, M. L. (1994) Predictive maintenance: its present state and future potential for the mobile equipment industries. In: Proc of the Conference Equipment resource man- agement into the $21^{\text {st }}$ century, Nashville, Tennessee, ASCE, New York. 210 p.

d'Inverno, M. and Luck, M. (2001) Understanding agent systems. Springer Verlag, Berlin-Heidelberg-New York. $191 \mathrm{p}$.

Nwana, H. S. (1996) Software agents: an overview. Knowledge Engineering Review, 11(3), p. 205-244.

Ren, Z. and Anumba, C. J. (2004) Multi-agent systems in construction - state of the art and prospects. Automation in Construction, 13(3), p. 421-434.

Russell, S. and Norvig, P. (1995) Artificial Intelligence: A Modern Approach. Englewood Cliffs, NJ: Prentice Hall. $1080 \mathrm{p}$.

SAP (2003) Engineering, Construction \& Operations - Edition 2004, http://www.sap.com/businessmaps/ (as viewed on 5/3/2004).

Schaufelberger, J. E. (1999) Construction Equipment Management. Prentice-Hall, Inc., Upper Saddle River, New Jersey. $357 \mathrm{p}$.

Selker, T. (1994) A teaching agent that learns. Communications of the ACM, 37(7), p. 92-99.

Tavakoli, A., Taye, E. D., and Erktin, M. (1989) Equipment policy of top 400 contractors: a survey. ASCE Journal of Construction Engineering and Management, 115(2), p. 317-329.

\section{INTEGRUOTAS AGENTINIS IৃRANGOS VALDYMAS: KONCEPCINIAI SPRENDIMAI}

\section{O. Tatari and M. Skibniewski}

\section{Santrauka}

Efektyvus ịrangos valdymas yra labai svarbus sėkmingos statybos įmonės veiklos veiksnys. Neadekvatūs ịrangos valdymo sprendimai, netaikant automatizuotų valdymo sistemų, yra subjektyvūs. Dèl to dažnai statybos įmonè, taip pat ir visa ekonomika gali patirti didelių nuostolių. Pagrindinis šio straipsnio tikslas yra pristatyti agentinę ịrangos valdymo sistemą integracijai ir automatizacijai didinti ir kartu sprendimų priemimo klaidoms sumažinti. Naujausi agentinių technologijų tyrimai leidžia taikyti automatizuotą ir integruotą irangos valdymo sistemą. Siūloma sistema remiasi esama statybos įmonių duomenų baze ir ịdiegia belaides statybos ịrangos technologijas automatizuotai duomenims integruoti.

Reikšminiai žodžiai: ịrangos valdymas, agentinès technologijos, statybos pramonè.

Omer TATARI. PhD Candidate in the Dept of Civil Engineering at Purdue University. His research interest is in the area of Enterprise Resource Planning and its applicability to the construction industry. Also, he holds an MS degree in Industrial Engineering. He is pursuing his PhD at Purdue University, USA, under the direction of Prof M. Skibniewski.

Mirosław SKIBNIEWSKI. A. James Clark Endowed Chair Professor in Construction Engineering and Project Management in the Dept of Civil and Environmental Engineering at the University of Maryland, USA. Editor-in-Chief of "Automation in Construction" (an international research journal published by Elsevier), and Past President of the International Association for Automation and Robotics in Construction. He received the Presidential Young Investigator Award from the US National Science Foundation and the Walter L. Huber Research Prize from the American Society of Civil Engineers. A former Humboldt and Fulbright grantee, he is a Honorary Professor of Warsaw University of Technology and Moscow State Industrial University, as well as a Foreign Member of the Russian Academy of Engineering. 